\title{
Comparison of adhesive strength of resinous teeth splinting materials according to enamel surface treatment
}

\author{
Ye-Rim Lee, Soo-Yeon Kim, Jin-Woo Kim, Se-Hee Park, Kyung-Mo Cho* \\ Department of Conservative Dentistry, College of Dentistry, Gangneung-Wonju National University School of Dentistry, Gangneung, \\ Republic of Korea
}

Purpose: The purpose of this study is to compare and analyze the shear bond strength and fracture pattern in different enamel tooth surface treatments for resin splinting materials. Materials and Methods: G-FIX and LightFix were used as tooth splinting materials. Twenty bovine mandibular incisors were used for the preparation of the specimens. The exposed enamel surface was separated into four parts. Each tooth was treated with 37\% phosphoric acid, 37\% phosphoric acid + adhesive resin, 37\% phosphoric acid + G-premio bond, and G-premio bond for each fraction. Shear bond strength was measured using a universal testing machine. After measuring the shear bond strength, the fractured surface of the specimen was magnified with a microscope to observe the fracture pattern. Two-way ANOVA was used to verify the interaction between the material and the surface treatment method. Oneway ANOVA was used for comparison between the surface treatment methods of each material and post-hoc test was conducted with Scheffe's test. An independent t-test was conducted to compare shear bond strengths between materials in each surface treatment method. All statistics were conducted at 95\% significance level. Results: G-FIX, a tooth splinting resin, showed similar shear bonding strength when additional adhesive resins were used when material was applied after only acid etching, and LightFix showed the highest shear bonding strength when additional adhesive resins were used after the acid etching. In addition, both G-FIX and LightFix showed the lowest shear bond strength when only self-etching adhesive was applied without additional acid etching. Verification of interactions observed interconnection between resins and surface treatment methods. Most of the mixed failure was observed in all counties. Conclusion: When using G-FIX and LightFix, which are tooth-splinting materials, it is considered that sufficient adhesion will be achieved even after applying only acid etching as instructed by the manufacturer. (J Dent Rehabil Appl Sci 2019;35(2):72-80)

Key words: enamel; shear bond strength; splinting; surface treatment; tooth mobility

\begin{abstract}
서론
치아의 비생리적인 동요는 외상성 교합, 치아의 외상, 치주질환 등에 의해 발생한다. 임상에서 심한 동요를 보 이는 치아에서 다양한 이유들로 인해 치아의 유지가 결 정된 경우 치아에 대한 고정 술식이 행해질 수 있다. 고정 (splinting)이란 두 개 혹은 그 이상의 치아를 고정성 혹은

가철성 수복물이나 장치를 이용하여 단단하게 고정시키 는 것으로 ${ }^{1}$ 환자의 불편감을 해소하고 교합관계와 저작 기능을 회복시키며, ${ }^{2}$ 저작 등의 기능 중 생기는 하중을 여 러 치아와 넓은 면적으로 분산시키고 해로운 측방 하중 을 수직적인 방향으로 바꿔줌으로써 동요치의 치주적 예 후를 개선시키는 것을 목표로 한다. ${ }^{3}$

여러 방법 중, 인접치의 법랑질에 직접 재료를 접착시 
켜 고정을 도모하는 레진 치아 고정은 치아 삭제가 거의 필요하지 않아 보존적이고 임상에서 적용이 간편하고 술 식 시간이 빠르며 심미적으로 우수하다는 장점을 지니 며, 비교적 구강위생을 방해하지 않으며 추가적인 진단 과 치료가 가능하다는 장점이 있다. ${ }^{4}$ 이러한 장점들로 인 해 레진 치아 고정은 동요치 고정을 위한 고정 방법 중 널 리 사용되고 있는 방법 중 하나로 최근에는 레진 치아 고 정을 위한 전용 제품도 개발되어 출시되어 사용되고 있 다. 치아고정 재료를 포함한 구강내의 수복물은 온습한 환경에서 장기간 저작압에 노출되며 스트레스를 받으며 이로 인해 재료 자체의 파절 또는 치아와 수복재의 계면 의 부착 실패의 중요한 원인이 될 수 있다. ${ }^{5}$ 그러므로 구 강 내 환경에서 파절되지 않기 위해 높은 강도와 법랑질 에의 믿을만한 접합 강도가 요구된다. 법랑질 접착에 대 한 연구는 1955년 Buonocore ${ }^{6}$ 에 의해 법랑질에 대한 산 부식술이 소개되며 법랑질의 표면에 미세한 요철 구조가 생기게 되고 이 미세 구조로 레진이 침입하여 기계적 결 합을 이룬다는 사실을 발견한 이후로 진행되어 왔다.

현재 치아 고정용으로 나오는 레진에는 G-FIX (GC, Tokyo, Japan)와 LightFix (Sun Medical, Shiga, Japan)가 있다. 두 종류의 치아 고정용 레진은 제조사의 지시에 따 르면 산부식만 시행한 후 접착하게 되어있다. 그러나 현 재 레진의 접착을 위해 사용하는 접착 시스템은 다양하 다. 이에 본 연구에서는 동요치 고정에 사용될 수 있는 레 진계 치아고정 재료의 사용 시 치면 처리 방법이 법랑질 에 대한 접착력에 미치는 영향을 알아보기 위하여 4가지 치면 처리 방법을 이용하고 법랑질에 대한 전단결합강도 와 파절 양상을 비교함으로써 임상에서의 유용성을 평가 하고 임상가들이 재료를 선택함에 있어 도움이 되고자 하였다.

\section{연구 재료 및 방법}

실험군으로 2 종의 치아 고정용 레진을 사용하였다. 광 중합 스플린트 재료인 G-FIX, LightFix를 사용했다. 접 착을 위해 $37 \%$ 인산인 Spot-On (Premier, Norristown, USA), 접착 레진인 Adper Scotchbond Multi-purpose Adhesive (3M, St Paul, USA), 자가부식 접착제인 Gpremio bond (GC)를 사용했다. 각 재료의 구성성분은 Table 1에 나타내었다.

접착제와 레진의 중합을 위해 $\mathrm{LED}$ 광중합기인 G-Light (GC)를 사용하였다.

\section{법랑질 시편 제작}

Ando 등에 의한 시편 제작 방법을 참고하여 시편을 제작한 후 연마하였다. 치관부에 결함이 없는 소의 하 악 절치 20 개를 사용하였으며 발치 후 $4^{\circ} \mathrm{C}$ 증류수에 보 관하고 2 개월 이내에 사용하였다. 치아를 임의로 10 개 씩 G-FIX군과 LightFix군으로 분류하였다. 백악법랑경 계에서 치관을 자른 후, 치수강의 치수를 제거하고 $2.5 \%$ $\mathrm{NaOCl}$ 에 30분간 담근 뒤 임시 충전재인 Caviton (GC) 으로 밀봉하였다. 치관의 순면이 노출되게 하여 $25 \times 18$ $\times 8 \mathrm{~mm}$ 크기의 투명한 아크릴릭 레진에 매몰하였다. 320 grit, 600 grit의 실리콘 카바이드 페이퍼를 순서대로 이용하여 균일한 법랑질 표면이 노출되도록 주수 하에 연마하였다.

노출된 법랑질 표면을 4 부분으로 구획을 나누어 각 각 다른 치면 처리를 한 뒤 내경 $2 \mathrm{~mm}$, 높이 $3 \mathrm{~mm}$ 원기 둥 모양의 Odontosil (Dreves, Unna, Germany)로 제작 한 실리콘 주형을 위치시킨 후 치아 고정용 레진을 2 회 에 걸쳐 $\mathrm{LED}$ 광중합기를 이용하여 20 초씩 적층 충전하 였다.

\section{치면 처리 방법에 따른 군 분류}

$\mathrm{E}$ 군(Etching군): 제조사의 지시에 따라 $37 \%$ 인산을 법 랑질 표면에 적용하여 30 초간 산부식 처리하고 쓰리웨이 시린지로 세척한 후 건조하였다.

$\mathrm{E}+\mathrm{A}$ 군(Etching + Adhesive resin군): 제조사의 지시 에 따라 $37 \%$ 인산을 법랑질 표면에 적용하여 30 초간 산 부식 처리하고 쓰리웨이 시린지로 세척한 후 건조하였다. Adper Scotchbond Multi-purpose Adhesive의 component 3 adhesive를 마이크로브러쉬를 이용하여 도포한 후 10 초간 광중합 하였다.

E+GP군(Etching + G-Premio Bond군): 제조사의 지 시에 따라 $37 \%$ 인산을 법랑질 표면에 적용하여 30 초간 산부식 처리하고 쓰리웨이 시린지로 세척한 후 건조하였 다. G-premio bond를 마이크로브러쉬를 이용하여 도포 하고 10 초 후 강한 바람으로 건조한 후 10 초간 광중합 하였다.

GP군(G-premio Bond군): G-premio bond를 마이크 로브러쉬를 이용하여 도포하고 10 초 후 강한 바람으로 건조한 후 10 초간 광중합 하였다. 
Table 1. Composition of materials used in this study

\begin{tabular}{|c|c|c|}
\hline Material & Manufactures & Composition \\
\hline G-FIX & GC & $\begin{array}{l}\text { Silane-treated-barium-glass } \\
\text {-Barium glass } \\
\text {-r-Methacryloxypropyltrimethoxysilane } \\
\text { Monomer (undiluted solution) } \\
\text {-Bisphenol A Ethoxylate Dimethacrylate } 1 \\
\text {-Bisphenol A Ethoxylate Dimethacrylate } 2 \\
\text {-Di-2-metharyloloxyethyl-2,2,4- } \\
\text {-methacryloxydecanoxyphosphate } \\
\text {-Camphoquinone } \\
\text {-Benzoicacid, p-(dimethylamino)-, ethyl ester } \\
\text {-2,4,6-Trimethylbenzoyldiphenylphosphine Oxide } \\
\text {-6-tert-Butyl-2,4-xylenol, } \\
\text { Silicon dioxide }\end{array}$ \\
\hline LightFix & Sun Medical & $\begin{array}{l}\text { 4-Methoxyphenol; } \\
\text { Diphenyl(2,4,6-trimethylbenzoyl)phosphine oxide, } \\
\text { 2,6-di-tert-butyl-p-cresol, } \\
\text { Silicon dioxide, } \\
\text { others }\end{array}$ \\
\hline $\begin{array}{l}\text { Adper Scotchbond Multipurpose } \\
\text { Adhesive component } 3 \text { (Adhesive) }\end{array}$ & 3M ESPE & Bis-GMA (60 - $70 \mathrm{Wt} \%$ ); HEMA (30 - $40 \mathrm{Wt} \%$ ); Initiator \\
\hline G-Premio Bond & GC & $\begin{array}{l}\text { 4-Methacryloxyethyl trimellitate anhydride, } \\
\text { 10-Methacryloyloxydecyl dihydrogen phosphate, } \\
\text { 2-Hydroxy 1,3-dimethacryloxypropane, } \\
\text { Triethyleneglycol dimethacrylate, } \\
\text { Distilled water, } \\
\text { Acetone, } \\
\text { Camphorquinone, } \\
\text { Ethyl p-dimethylaminobenzoate, } \\
\text { 2,4,6-Trimethylbenzoyl diphenylphosphineoxide, } \\
\text { 2,6-Di-tert-butyl-p-crezol, } \\
\text { Aluminium oxide, } \\
\text { Silicon dioxide, } \\
\text { 10-Methacryloyloxydecyl dihydrogen thiophosphate }\end{array}$ \\
\hline
\end{tabular}

Data from manufacturers' websites and/or product catalogs

\section{전단결합강도 측정}

Bermudez 등 $^{8}$ 의 전단결합강도 측정 방법을 참고하 여 만능 시험기(RB-306, R\&B Inc., Daejeon, Korea) 를 이용하여 최대 하중 $800 \mathrm{~kg}$ 의 조건에서 분당 $1.0 \mathrm{~mm}$ 의 cross-head speed로 치아 고정용 레진이 시편에서 탈 락할 때까지 전단 하중을 주었다. 이 때의 최대 하중을 Helio X 프로그램(R\&B Inc.)을 이용하여 구하고, 이를 단위 면적당 전단결합강도 $(\mathrm{MPa})$ 로 환산하였다. 전단결 합강도는 다음 공식에 따라 계산되었다.

전단결합강도 $\mathrm{R}(\mathrm{MPa})=F(\mathrm{~N}) / \mathrm{A}\left(\mathrm{mm}^{2}\right)$

\section{파절 양상 분석}

전단결합강도 측정 후, 시편의 파절된 표면을 현미경으 로 40 배 확대하여 파절 양상을 관찰하였다. 파절 양상에 따
라 접착제와 치아 계면에서 발생하는 부착성 파절 (Adhesive failure), 접착제 내에서 발생하는 응집성 파절(Cohesive failure in composite resin), 치아에서 발생하는 응집성 파절 (Cohesive failure in enamel), 위의 양상들이 혼합되어 나타나 는 혼합성 파절(Mixed failure)의 4가지 범주로 분류하였다.

\section{통계 분석}

검출된 결과를 검증하기 위해 SPSS ver 23.0 (IBM Corp., Chicago, USA)를 이용하여 분석하였다. Two-way ANOVA test를 이용하여 재료와 표면처리 방법 사이의 상호작용을 검증하였고 각 재료에서 표면처리 방법 사이 의 비교를 위해 One-Way ANOVA test를 하고 Scheffe's test로 사후 검정 하였다. 각 표면처리 방법에서 재료 사 이의 전단결합강도를 비교하기 위해 independent t-test 를 하였다. 모든 통계는 $95 \%$ 유의수준에서 진행하였다. 


\section{결과}

각 실험 재료의 전단결합강도의 평균과 표준편차를 Table 2에 나타내었다. 본 연구의 결과 G-FIX군에서 전단결합강도는 $\mathrm{E}$ 군의 접착 강도 $(23.09 \pm 1.67 \mathrm{MPa})$ 와 $\mathrm{E}+\mathrm{A}$ 군의 결합강도 $(21.04 \pm 2.12 \mathrm{MPa})$ 가 가장 높게 나타났으며 GP군이 가장 낮은 결합강도(16.32 \pm 2.64 $\mathrm{MPa}$ 를 나타냈다. LightFix군에서 전단결합강도는 $\mathrm{E}+\mathrm{A}$ 군이 가장 높은 결합강도 $(24.86 \pm 2.50 \mathrm{MPa})$ 를 나타냈으 며 $\mathrm{GP}$ 군이 가장 낮은 결합강도 $(9.48 \pm 1.65 \mathrm{MPa})$ 를 나 타냈다.

재료와 표면처리 방법 사이의 교호작용의 검증 결과 는 Table 3에서 제시하였으며, 사후검정시행 결과는 Fig. 1, Fig. 2에서 나타내었다. G-FIX군에서 각 치면 처리 방
법 간의 전단결합강도를 scheffe's test로 사후 검정한 결 과, $\mathrm{E}$ 군의 결합강도는 $\mathrm{E}+\mathrm{GP}$ 군과 $\mathrm{GP}$ 군보다 높게 나타 났고, $\mathrm{E}+\mathrm{A}$ 군의 결합강도는 GP군보다 높게 나타났으 며, GP군은 다른 모든 군보다 낮게 나타났다 $(P<0.05)$.

Table 2. Shear bond strength of Resin splinting materials [Mean $(\mathrm{MPa})$ and standard deviation]

\begin{tabular}{lcc}
\hline \multirow{2}{*}{ Group } & \multicolumn{2}{c}{ MPa, Mean \pm standard deviation } \\
& G-FIX & LightFix \\
\hline E & $23.09 \pm 1.67$ & $21.90 \pm 2.50$ \\
E+A & $21.04 \pm 2.12$ & $24.86 \pm 1.38$ \\
E+GP & $19.41 \pm 2.81$ & $13.83 \pm 2.70$ \\
GP & $16.32 \pm 2.64$ & $9.48 \pm 1.65$ \\
\hline
\end{tabular}

E: Etching; E+A: Etching+Adhesive resin; E+GP: Etching+G-Premio Bond; GP: G-premio Bond.

Table 3. Result of Two-way ANOVA test on shear bond strength of resin splinting materials

\begin{tabular}{lcccrc}
\hline Source & Sum of squares & df & Mean square & \multicolumn{1}{c}{ F } & Sig. \\
\hline Corrected Model & $1878.554^{\mathrm{a}}$ & 7 & 268.365 & 53.206 & .000 \\
Intercept & 28097.632 & 1 & 28097.632 & 5570.622 & .000 \\
Material & 119.977 & 1 & 119.977 & 23.786 & .000 \\
Surface & 1409.019 & 3 & 469.673 & 93.117 & .000 \\
Material $*$ Surface & 349.559 & 3 & 116.520 & 23.101 & .000 \\
Error & 363.160 & 72 & 5.044 & & \\
Total & 30339.347 & 80 & & & \\
Corrected Total & 2241.715 & 79 & & & \\
\hline
\end{tabular}

a.R Squared $=.838$ (Adjusted R Squared $=.822$ ), df: Degree of freedom, Sig: Significance.

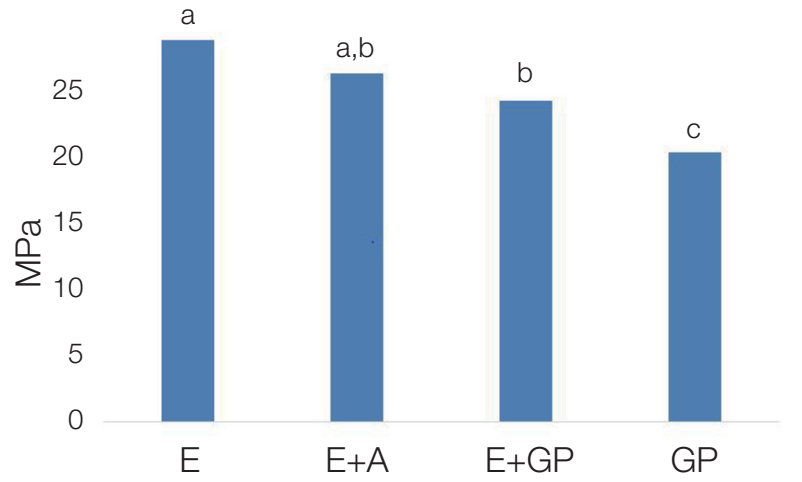

Fig. 1. Scheffe's test result of shear bond strength of G-FIX. The same alphabet characters on the bars indicate not significantly different $(P<0.05)$. E: Etching; $\mathrm{E}+\mathrm{A}$ : Etching+Adhesive resin; E+GP: Etching+G-Premio Bond; GP: G-premio Bond.

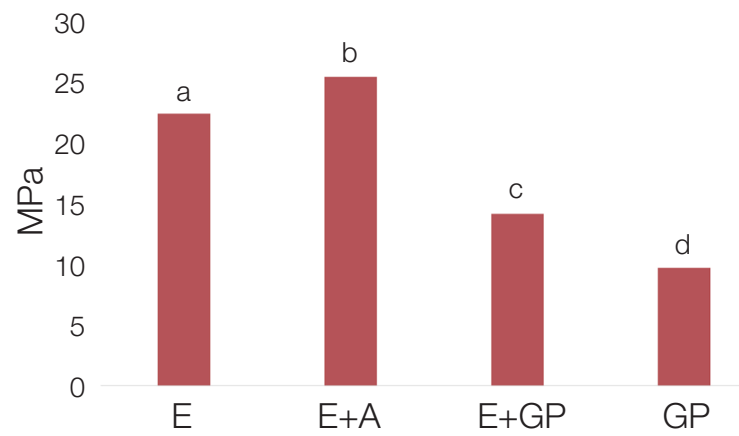

Fig. 2. Scheffe's test result of shear bond strength of LightFix. The different alphabet characters on the bars indicate the significant difference $(P<0.05)$. E: Etching; $E+A$ : Etching+Adhesive resin; $E+G P$ : Etching+G-Premio Bond; GP: G-premio Bond. 
LighFix군에서 각 치면 처리 방법 간의 전단결합강도를 scheffe's test로 사후 검정한 결과, 전단결합강도는 $\mathrm{E}+\mathrm{A}$ 군, $\mathrm{E}$ 군, $\mathrm{E}+\mathrm{GP}$ 군, $\mathrm{GP}$ 군 순으로 나타났으며 각각 통계 학적인 차이가 나타났다 $(P<0.05)$. Independent t-test 를 시행하여 재료 사이의 전단결합강도를 비교한 결과를 Fig. 3에 나타내었다.

G-FIX의 파절 양상을 Table 4에 나타내었다. 모든 군 에서 대부분 혼합성 파절(mixed failure)이 관찰되었으

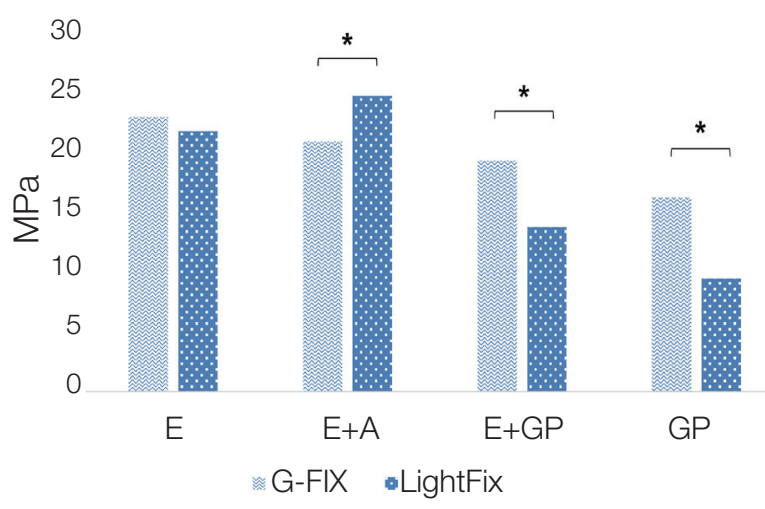

Fig. 3. Independent T-test result of shear bond strength of resin splinting materials. Statistical significantly different groups are denoted by an asterisk $(P<0.05)$. $E$ : Etching; $E+A$ : Etching+Adhesive resin; $E+G P$ : Etching +G-Premio Bond; GP: G-premio Bond.
며, E군에서 법랑질의 응집성 파절(cohesive failure in enamel)이 1 개의 시편에서 관찰되었고, E+GP군, GP군 에서 접착성 파절(adhesive failure)이 1개씩 관찰되었다.

LightFix의 파절 양상을 Table 5에 나타내었다. 모든 군에서 대부분 혼합성 파절(mixed failure)이 관찰되었으 며, E+GP군, GP군에서 접착성 파절(adhesive failure)이 2개씩 관찰되었다.

\section{고찰}

결합강도 실험을 위하여서는 발거된 사람의 치아를 이 용하는 것이 선호된다. ${ }^{10}$ 그러나 소의 치아는 많은 양을 얻기 쉽고 상태가 좋으며 사람의 법랑질보다 조성 변수 가 적다는 점과, ${ }^{11}$ 크고 평평한 표면을 가지고 있으며 시 험 결과에 영향을 줄 수 있는 우식증에 걸리지 않았을 가 능성이 낮다는 장점이 있다. 또한 법랑질 결합강도 평가 에서 소의 치아는 사람의 치아와 유사한 결과를 나타냈 으며 ${ }^{12}$ 소의 치아가 사람의 치아의 대체재로의 가능성이 입증된 바 있다. ${ }^{13}$ 따라서 본 연구에서는 소의 치아를 인 간 치아의 대체재로 사용했다.

법랑질에 대한 복합 레진의 결합강도는 수복물의 수명 에 영향을 주는 요소 중 하나이며, 치아 고정용 레진에서 도 마찬가지이다. 레진 접착 술식은 Buonocore ${ }^{6}$ 에 의해 소개되었으며 산부식을 통하여 접착력을 개선할 수 있 었다. 인산을 통한 산부식을 이용한 법랑질 접착은 수십

Table 4. Failure mode of G-FIX

\begin{tabular}{|c|c|c|c|c|c|}
\hline & Cohesive failure in enamel & Cohesive failure in resin & Adhesive failure & Mixed failure & No. of specimen \\
\hline $\mathrm{E}$ & 1 & 0 & 0 & 9 & 10 \\
\hline $\mathrm{E}+\mathrm{A}$ & 0 & 0 & 0 & 10 & 10 \\
\hline $\mathrm{E}+\mathrm{GP}$ & 0 & 0 & 1 & 9 & 10 \\
\hline GP & 0 & 0 & 1 & 9 & 10 \\
\hline
\end{tabular}

E: Etching; E+A: Etching+Adhesive resin; E+GP: Etching+G-Premio Bond; GP: G-premio Bond.

Table 5. Failure mode of LightFix

\begin{tabular}{|c|c|c|c|c|c|}
\hline & Cohesive failure in enamel & Cohesive failure in resin & Adhesive failure & Mixed failure & No. of specimen \\
\hline $\mathrm{E}$ & 0 & 0 & 0 & 10 & 10 \\
\hline $\mathrm{E}+\mathrm{A}$ & 0 & 0 & 0 & 10 & 10 \\
\hline $\mathrm{E}+\mathrm{GP}$ & 0 & 0 & 2 & 8 & 10 \\
\hline GP & 0 & 0 & 2 & 8 & 10 \\
\hline
\end{tabular}

E: Etching; E+A: Etching+Adhesive resin; E+GP: Etching+G-Premio Bond; GP: G-premio Bond. 
년 동안 치과에서 유용하고 성공적인 방법으로 입증되 었다. 법랑질은 인산에 의해 표층에 미세한 함몰부가 형 성되고, 이 부위에 접착 레진이 흘러 들어가, 레진 태그를 형성하고 미세기계적인 유지를 통해 법랑질과 복합 레진 간에 우수한 접착을 제공한다. ${ }^{14}$ 따라서 법랑질에 대한 접착력은 법랑질의 표면에 형성되어 있는 함몰 형태의 형 성 정도에 의해 좌우된다고 알려져 있다. ${ }^{6}$ 반면에 자가부 식 접착제의 경우 인산에 비해 낮은 산도의 친수성의 산 성 단량체를 사용함으로써 법랑질의 부식 처리와 단량 체의 침투를 동시에 수행한다. ${ }^{15}$ 그러나 자가부식 접착 제에 의해 탈회를 시행하면 프라이머의 산성이 법랑질에 서 점차 중화되기 때문에 점차 탈회가 멈추게 된다. ${ }^{16}$ 또 한 산부식 과정을 시행한 경우 탈회 정도가 뚜렷한 양상 을 보이지만, 자가부식 접착제는 불규칙한 양상을 보인 다고 하였고 이는 결합강도 결과에 영향을 주는 요소 중 하나라고 평가되고 있다. ${ }^{17}$ 그러나 현재 출시되고 있는 'universal' 형태의 자가부식 접착제는 법랑질에 미세기계 적인 유지 뿐만 아니라 10-MDP (10-methacryloyloxydecyl-dihydrogen-phosphate), 4-MET (4-methacryloxyethyl trimellitate)와 같은 기능성 단량체와 수산화인회석 의 칼슘 성분 사이에 화학적인 결합 반응을 기할 수 있는 장점을 가지고 있다. ${ }^{18}$ 그러나 이전의 연구들에 의하면 자 가부식 접착제의 사용시 추가적인 인산으로의 산부식을 시행하는 것이 법랑질 접착에 효과적이라는 것이 입증되 었다. ${ }^{19-22}$

G-FIX의 경우 제조사에서는 인산 에스테르 모노머를 배합하여 접착제를 사용하지 않아도 산부식한 법랑질에 높은 접착성을 발휘한다고 ${ }^{23}$ 설명하고 있다. 본 연구의 실 험 결과 G-FIX에서 $\mathrm{E}$ 군이 $\mathrm{E}+\mathrm{A}$ 군과 $\mathrm{E}+\mathrm{GP}$ 군보다 더 높은 접착 강도를 보이며 제조사의 지시와 일치하는 결 과를 보였는데, 이는 인산 에스테르와 같은 산성 단량체 에 포함된 인산 기에 의해서 법랑질이 부식되고, 산성 단 량체에 포함된 메타크릴산염기(methacrylate기)에 의해 서 레진과 공중합 함으로써 접착을 이루게 되기 때문 ${ }^{24}$ 으 로 생각할 수 있다. 이 중, E군과 E+GP군 사이에만 유 의한 차이를 나타내고 있는데, 이는 G-Premio Bond가 제조사의 설명에 의하면 $\mathrm{pH}$ 1.5로 표기되어 있으며 치 아 표면에 남아 있는 자가부식 접착제의 낮은 $\mathrm{pH}$ 가 접착 층의 상부에서 레진의 중합을 억제할 수 있기 때문 ${ }^{25}$ 으로 생각할 수 있다. 또한, G-Premio Bond의 구성 성분 중 아세톤이 증발되며 법랑질의 미세 공포로 레진이 충분 히 침투되지 못하였기 때문이라고 추측할 수 있으나 이
에 대해서는 추가적인 연구가 필요하다. LightFix에서는 $\mathrm{E}+\mathrm{A}$ 군이 $\mathrm{E}$ 군 보다 유의하게 높은 결합강도를 보였는 데, 이는 산부식된 법랑질 표면에 미세한 함몰부가 형성 되고, 이 부위에 접착 레진이 흘러 들어가 법랑질과 미세 기계적인 결합을 이루었기 때문에 ${ }^{26}$ 접착 레진을 적용한 군에서 더 높은 전단결합강도를 보인다고 생각할 수 있 다. LightFix의 E+GP군과 GP군은 G-FIX의 E+GP군 과 GP군에 비해 낮은 결합강도를 보였다. 접착제 성분에 포함된 모노머들과 용매제 등 다른 요소가 법랑질에 대 한 결합강도에 영향을 주었을 것으로 보이며, ${ }^{27}$ 이를 밝 혀내기 위한 LightFix와 G-Premio Bond의 성분에 관한 추가적인 연구가 필요하다. 본 연구에서 모든 치아 고정 용 레진에서 별도의 산부식 없이 자가부식 접착제만으로 치면 처리를 한 경우, 유의하게 낮은 결합강도를 보였는 데, 이전의 연구들과 같은 결과를 ${ }^{19-22}$ 보여주며 법랑질에 자가부식 접착제를 사용할 때 추가적인 산부식이 필요함 을 입증하였다.

파절 양상을 살펴보면 대부분 혼합성 파절이 관찰되었 는데, 결합강도가 높은 G-FIX의 E군에서 법랑질에서의 응집성 파절이 1 개 관찰되었으며 상대적으로 낮은 결합 강도를 보인 LightFix의 E+GP군, GP군에서 가장 많은 비율의 접착성 파절이 관찰되었다.

본 연구는 치면 처리 방법에 따른 법랑질에 대한 치아 고정용 레진의 전단결합강도와 파절 양상을 평가한 것으 로, 동요치 고정을 목적으로 개발된 G-FIX와 LightFix 는 제조사의 지시와 같이 산부식만 시행한 후 재료를 적 용해도 충분한 접착이 이루어질 것으로 생각되며, 자가 부식 접착제의 단독 사용은 추천되지 않는다. 그러나 이 는 법랑질에 치아 고정용 레진을 접착한 24시간 이후에 실험한 것으로, 실제 구강내의 수복물은 온습한 환경에 장기간 노출된다는 점을 고려한 좀더 다양하고 장기적인 연구를 진행하면 더 정확한 임상적 의의가 있을 것으로 생각된다. 또한 성공적인 치아고정을 위해서는 이번 연구 에서 조사한 결합강도뿐만 아니라 굴곡강도, 탄성계수, 용해도, 생체 적합성, 중합 수축, 심미성, 조작성 등 다양 한 요소가 복합적으로 고려되어야 한다.

\section{결론}

동요치의 고정에 사용되는 레진계 치아고정 재료의 치 면 처리 방법에 따른 전단결합강도를 측정한 결과는 다 음과 같다. 
동요치 고정을 위한 G-FIX는 산부식만 시행한 후 재 료를 적용해도 접착 레진을 추가적으로 사용했을 때와 유사한 전단결합강도를 보였으며 LightFix는 산부식을 시행한 후 접착 레진을 추가적으로 사용했을 때 가장 높 은 전단결합강도를 보였다.

동요치 고정을 위한 G-FIX와 LightFix는 자가부식 접 착제만 단독 처리 후 사용했을 때 가장 낮은 전단결합강 도를 나타내었다.

이상의 결과를 종합해 볼 때, 치아 고정용 레진인 G-FIX와 LightFix의 제조사의 지시와 같이 산부식만 시 행한 후 재료를 적용해도 충분한 접착이 이루어질 것으 로 생각되며, 자가부식 접착제의 단독 사용은 추천되지 않는다.

\section{ORCID}

Ye-Rim Lee https://orcid.org/0000-0001-6547-2605

Soo-Yeon Kim http://orcid.org/0000-0001-7437-6877

Jin-Woo Kim https://orcid.org/0000-0002-0004-0710

Se-Hee Park https://orcid.org/0000-0002-4052-4082

Kyung-Mo Cho https://orcid.org/0000-0003-3464-9425

\section{References}

1. Liu X, Zhang Y, Zhou Z, Ma S. Retrospective study of combined splinting restorations in the aesthetic zone of periodontal patients. Br Dent J 2016;220:241-7.

2. Bernal G, Carvajal JC, Muñoz-Viveros CA. A review of the clinical management of mobile teeth. J Contemp Dent Prac 2002;3:10-22.

3. Mazzoleni S, Meschia G, Cortesi R, Bressan E, Tomasi C, Ferro R, Stellini E. In vitro comparison of the flexibility of different splint systems used in dental traumatology. Dent Traumatol 2010;26:30-6.

4. Yoo JI, Kim SY, Batbayar B, Kim JW, Park SH, Cho KM. Comparison of flexural strength and modulus of elasticity in several resinous teeth splinting materials. J Dent Rehabil Appl Sci 2016;32:169-75.

5. Wood M, Kern M, Thompson VP, Romberg E. Ten-year clinical and microscopic evaluation of resin-bonded restorations. Quintessence Int 1996;27:803-7.
6. Buonocore MG. A simple method of increasing the adhesion of acrylic filling materials to enamel surfaces. J Dent Res 1955;34:849-53.

7. Ando S, Watanabe T, Tsubota K, Yoshida T, Irokawa A, Takamizawa T, Kurokawa H, Miyazaki M. Effect of adhesive application methods on bond strength to bovine enamel. J Oral Sci 2008;50:1816.

8. Bermudez L, Wajdowicz M, Ashcraft-Olmscheid D, Vandewalle K. Effect of Selective Etch on the Bond Strength of Composite to Enamel Using a Silorane Adhesive. Oper Dent 2015;40:E242-9.

9. Oskoee SS, Bahari M, Kimyai S, Navimipour EJ, Firouzmandi M. Shear bond strength of self-etching adhesive systems with different $\mathrm{pH}$ values to bleached and/or CPP-ACP-treated enamel. J Adhes Dent 2012;14:447-52.

10. Fowler CS, Swartz ML, Moore BK, Rhodes BF. Influence of selected variables on adhesion testing. Dent Mater 1992;8:265-9.

11. Edmunds DH, Whittaker DK, Green RM. Suitability of human, bovine, equine, and ovine tooth enamel for studies of artificial bacterial carious lesions. Caries Res 1988;22:327-36.

12. Soares FZ, Follak A, da Rosa LS, Montagner AF, Lenzi TL, Rocha RO. Bovine tooth is a substitute for human tooth on bond strength studies: A systematic review and meta-analysis of in vitro studies. Dent Mater 2016;32:1385-93.

13. Reis AF, Giannini M, Kavaguchi A, Soares CJ, Line SR. Comparison of microtensile bond strength to enamel and dentin of human, bovine, and porcine teeth. J Adhes Dent 2004;6:117-21.

14. Shimada Y, Senawongse P, Harnirattisai C, Burrow MF, Nakaoki Y, Tagami J. Bond strength of two adhesive systems to primary and permanent enamel. Oper Dent 2002;27:403-9.

15. Sano H, Shono T, Sonoda H, Takatsu T, Ciucchi B, Carvalho R, Pashley DH. Relationship between surface area for adhesion and tensile bond strengthevaluation of a micro-tensile bond test. Dent Mater 1994;10:236-40.

16. Pashley DH, Carvalho RM. Dentine permeability and dentine adhesion. J Dent 1997;25:355-72.

17. Hayakawa T, Kikutake K, Nemoto K. Influence 
of self-etching primer treatment on the adhesion of resin composite to polished dentin and enamel. Dent Mater 1998;14:99-105.

18. Yoshida Y, Nagakane K, Fukuda R, Nakayama Y, Okazaki M, Shintani H, Inoue S, Tagawa Y, Suzuki K, De Munck J, Van Meerbeek B. Comparative study on adhesive performance of functional monomers. J Dent Res 2004;83:454-8.

19. Erickson RL, Barkmeier WW, Kimmes NS. Bond strength of self-etch adhesives to pre-etched enamel. Dent Mater 2009;25:1187-94.

20. Miguez PA, Castro PS, Nunes MF, Walter R, Pereira PN. Effect of acid-etching on the enamel bond of two self-etching systems. J Adhes Dent 2003;5:10712.

21. Lührs AK, Guhr S, Schilke R, Borchers L, Geurtsen W, Günay H. Shear bond strength of self-etch adhesives to enamel with additional phosphoric acid etching. Oper Dent 2008;33:155-62.

22. Barkmeier WW, Erickson RL, Kimmes NS, Latta MA, Wilwerding TM. Effect of enamel etching time on roughness and bond strength. Oper Dent 2009;34:217-22.

23. Park BY, Kim SY, Kim JW, Park SH, Cho KM. Influence of water absorption on flexural strength and elastic modulus in several resinous teeth splinting materials. J Dent Rehabil Appl Sci 2018;34:729.

24. Hannig M, Reinhardt KJ, Bott B. Self-etching primer vs phosphoric acid: an alternative concept for composite-to-enamel bonding. Oper Dent 1999;24:172-80.

25. Tay FR, King NM, Suh BI, Pashley DH. Effect of delayed activation of light-cured resin composites on bonding of all-in-one adhesives. J Adhes Dent 2001;3:207-25.

26. Ferrari M, Mason PN, Vichi A, Davidson CL. Role of hybridization on marginal leakage and bond strength. Am J Dent 2000;13:329-36.

27. Van Meerbeek B, Yoshihara K, Yoshida Y, Mine A, De Munck J, Van Landuyt KL. State of the art of self-etch adhesives. Dent Mater 2011;27:17-28. 


\section{법랑질 표면 처리방법에 따른 레진계 치아 고정재료의 접착강도 비교}

\section{이예림, 김수연, 김진우, 박세희, 조경모*}

강릉원주대학교 치과대학 치과보존학교실

목적: 본 연구의 목적은 레진계 치아고정 재료의 법랑질 치면 처리 방법에 따른 전단결합강도와 파절 양상을 비교 분석 하는 것이다.

연구 재료 및 방법: 레진계 치아고정 재료로 G-FIX, LightFix를 사용하였다. 시편 제작을 위해 소의 하악 절치 20개를 사 용했다. 노출된 법랑질 표면을 4부분으로 구분하여, 각 분획 마다 $37 \%$ 인산(E), $37 \%$ 인산+Adhesive resin (E+A), $37 \%$ 인산+G-premio bond (E+GP), G-premio bond (GP)로 각각의 치면 처리를 하고, 재료를 접착하였다. 만능 시험기를 이용하여 전단결합강도를 측정하였고, 시편의 파절된 표면을 현미경으로 확대하여 파절 양상을 관찰하였다. Two-way ANOVA를 이용하여 재료와 표면처리 방법 사이의 상호작용을 검증하였고 각 재료에서 표면처리 방법 사이의 비교를 위 해 One-Way ANOVA test를 하고 Scheffe's test로 사후 검정 하였다. 각 표면처리 방법에서 재료 사이의 전단결합강도를 비교하기 위해 independent t-test를 하였다. 모든 통계는 95\% 유의수준에서 진행하였다.

결과: 동요치 고정을 위한 G-FIX는 산부식만 시행한 후 재료를 적용해도 접착 레진을 추가적으로 사용했을 때와 유사 한 전단결합강도를 보였으며 LightFix는 산부식을 시행한 후 접착 레진을 추가적으로 사용했을 때 가장 높은 전단결합 강도를 보였다. 또한, G-FIX와 LightFix 모두에서 별도의 산부식 없이 자가부식 접착제만 처리했을 때 가장 낮은 전단결 합강도를 보였다. 교호작용의 검증 결과 치아고정용 레진과 표면처리 방법 사이의 상호 연관됨이 관찰되었다. 파절 양상 은 모든 군에서 대부분 혼합성 파절이 관찰되었다.

결론: 치아 고정용 레진인 G-FIX와 LightFix의 사용시 제조사의 지시와 같이 산부식만 시행한 후 재료를 적용해도 충분 한 접착이 이루어질 것으로 생각된다.

(구강회복응용과학지 2019;35(2):72-80)

주요어: 법랑질; 전단결합강도; 고정; 치면 처리; 치아 동요

*교신저자: 조경모

(25457)강원도 강릉시 죽헌길 7 강릉원주대학교 치과대학 치과보존학교실

Tel: 033-640-3155 | Fax: 033-640-3103 | E-mail: drbozon@gwnu.ac.kr

접수일: 2019년 3월 6일 | 수정일: 2019년 4월 3일 | 채택일: 2019년 4월 29일 